\title{
Bilim İnsanlarının Sahip Oldukları Risklere Yönelik Ortaokul Öğrencilerinin Algıları
}

\author{
Perceptions of Secondary School Students About Risks of Scientists \\ Azize DİGILLLI-BARAN ${ }^{1}$, Sedat KARAÇAM ${ }^{2}$ \\ • Geliș Tarihi: 26.07.2019 • Kabul Tarihi: 02.03.2020 • Çevrimiçi Yayın Tarihi: 02.03.2020
}

\begin{abstract}
Öz
Bu çalışmanın amacı, ortaokul öğrencilerinin bilim insanlarının sahip oldukları risklere yönelik algılarını tespit etmektir. Nitel araştırma yöntemlerinden fenomenolojinin kullanıldığı bu çalışmaya beş, altı ve yedinci sınıflarda öğrenim gören 592 öğrenci katılmıştır. Öğrencilerin bilim insanlarının sahip oldukları risklere ilişkin algılarını belirlemek için açık uçlu soruların yer aldığ 1 anket uygulanmıştır. Yapılandırılmış görüş formunda elde edilen veriler içerik analizi ile analiz edilmiştir. Verilerin analizi sonucunda çevreyi ve toplumu etkileyen, araç gereç ve deneklere yönelik ve bilim insanını etkileyen riskler temaları oluşturulmuştur. Bunlardan en çok öğrencilerin bilim insanının kendini etkileyen fiziksel, ekonomik, sosyolojik, emeğe yönelik ve psikolojik risklere sahip olduklarını belirttikleri bulunmuştur. Öğrencilerin en fazla fiziksel riskler temasına vurgu yaptıkları ve bu temada ise en fazla patlama sonucu yaralanma veya ölme riskine vurgu yaptıkları görülmüştür. Diğer temalarda ise, ekonomik risklerden patlama sonucu mal varlığını kaybetme, sosyolojik risklerde toplumdan uzaklaşma veya evlenememe, emeğe yönelik risklerde çalışma sonucuna ulaşamama ve psikolojik risklerde çok çalışmaktan delirme riskine vurgu yaptıkları bulunmuştur. Her ne kadar risk algıları ortaya konulmuşsa da bu algıların onların kariyer seçimleri üzerine etkisi olup olmayacağı konusu hala açık değildir. Bundan sonraki çalışmalarda bu risk algılarının kariyer seçimleri üzerine etkisinin olup olmadığı ve etkisi varsa bireylerin bu risk algılarını olumlu yönde nasıl revize edebileceğine yönelik araştırmaların yapılması gerekmektedir.
\end{abstract}

Anahtar sözcükler: bilim insanı, kariyer seçimi, bilim insanı risk algıs1

\section{Atuf:}

Digilli-Baran, A. ve Karaçam, S. (2020). Bilim insanlarının sahip oldukları risklere yönelik ortaokul öğrencilerinin algıları. Pamukkale Üniversitesi Eğitim Fakültesi Dergisi, 50, 269-290. doi: 10.9779/pauefd.597429

\footnotetext{
1 Arş. Gör. Dr., Düzce Üni. Eğitim F. Matematik ve Fen Bilimleri Eğitimi Böl., azizedigillibaran@gmail.com, https://orcid.org/0000-0002-1197-9838

2 Doç. Dr., Düzce Üni. Eğitim F. Matematik ve Fen Bilimleri Eğitimi Böl., skaracam2000@,gmail.com, https://orcid.org/0000-0001-7610-3848
} 


\begin{abstract}
The aim of this study is to determine the perceptions of secondary school students' about the risks of being scientists. 592 students in five, six and seventh grade participated in this study. Phenomenology, one of the qualitative research methods, was used in this study. The data obtained in the structured opinion form was analyzed by content analysis. As a result of the analysis of the data, the themes of risks that affect the environment and the society, directed towards equipment and subjects and affect the scientist are created. Most of the participants stated that they have physical, economical, sociological, labor-oriented and psychological risks affecting the scientist. It was observed that the participants emphasized the theme of physical risks and the most and the highest risk of injury or death due to explosion was observed in this theme. And another themes, they emphasized losing assets as a result of the explosion about economic risks, asociality or not getting married about sociological risks. Also they emphasized inability to reach the result of working in labor-oriented risks and dementing because of working in psychological risks. In this study, risk perceptions were presented. In the following studies, it is necessary to investigate whether these risk perceptions have an effect on their career choices and if so, how individuals can revise these risk perceptions positively.
\end{abstract}

Keywords: scientist, career choice, perception of risk about scientist

\title{
Cited:
}

Digilli-Baran, A. \& Karaçam, S. (2020). Perceptions of secondary school students about risks of scientists. Pamukkale Üniversitesi Ĕ̌itim Fakültesi Dergisi, 50, 269-290. doi: 10.9779/pauefd.597429 


\section{Giriş}

Modern dünyada, bilimsel bilginin ve bilimsel başarıların rolü ile ilerleneceği açıktır. Çünkü bilim, kültürün bir parçası, ticaretin temeli ve insanın manevi ihtiyacı olarak görülmektedir (Lamanauskas ve Augiene, 2011). Fakat gelişmiş ülkeler başta olmak üzere birçok ülkedeki gençlerin bilim alanlarında kariyer yapma eğilimleri düşüktür. Ülkemizde de başta fizik ve kimya bölümleri olmak üzere birçok temel bilim alanlarına gençlerin ilgisi azalmakta böylece bu alanlara kayıt oranı da giderek azalmaktadır. On yaşındaki çocukların çoğunun bilime karşı olumlu tutuma sahipmiş gibi görünmelerine rağmen (Sturman, Ruddock, Burge, Styles, Lin ve Vappula, 2008), yıllar geçtikçe ve özellikle de ortaokula geçiş sırasında bilime karşı olan ilgilerinin azaldığ1 (Hutchinson, Stagg ve Bentley, 2009; Osborne, Simon ve Collins, 2003; Archer, DeWitt, Osborne, Dillon, Willis, ve Wong, 2010; White ve Harrison, 2012; Cerinsek, Hribar, Glodez, ve Dolinsek, 2013) ve ilerleyen eğitim hayatı boyunca sürekli azalan sayıda öğrencinin bilim derslerini çalışmayı seçtiği (Lyons ve Quinn, 2010) ya da yaşları ilerledikçe ileride bilimle ilgili meslek seçmek istemedikleri (Jenkins ve Nelson, 2005) ortaya konulmuştur. $\mathrm{Bu}$ ilginin azalmasının birçok nedeni vardır. Bu nedenlerden birisi bireylerin bilim ve bilim insanına yönelik sahip oldukları algılardır. Özellikle bireylerin sahip oldukları bilim insanı imgelerine odaklanan bazı araştırmacılar (She, 1998; Çermik, 2013; Karaçam, 2015; Karaçam ve Digilli-Baran, 2017) bireylerin bilim insanını kel, gözlüklü, laboratuvar önlüklü, laboratuvarda kimyasal araç gereçlerle tek başına devamlı çalışan bir insan olarak imgelediklerini ve bu imge nedeniyle bilim ve bilim insanına yönelik olumsuz tutum geliştirdiklerini ileri sürmüşlerdir. Bu bulgu önemli bir tespittir. Fakat alan yazında bu imgenin arkasında yatan bireylerin bilim insanının sahip olduğu risklere yönelik algılarını tespit etmeye çalışan bir araştırmaya rastlanmamıştır. Bireylerin kariyer seçiminde risk algıları çok önemlidir. Çünkü bireyler bir uğraşı seçerken riskleri satın alıp alamayacaklarını test eder ve karar verirler. Bu bakımdan bu çalışmada ortaokul öğrencilerinin bilim insanının sahip olduğu risklere yönelik algıları tespit edilmeye çalışılmıştır.

\section{Bilim Alanında Kariyer Yapmayı Etkileyen Etmenler}

Bilim, insanoğlu tarafindan icra edilen kültür hazinesi ve insanoğlunun düşünsel ürünüdür. Düşünsel bir faaliyet olan bilime katkı sağlayacak bireylerin gözlem yapma, sınıflama, deney yapma, veri toplama, ölçme ve verilerini yorumlayarak çıkarımlarda bulunma gibi bilimsel süreç becerilerinin (Anagün ve Yaşar, 2009) yüksek olması beklenir. Bu becerilerin geliştirilmesi, bireylerin bu becerilerinin farkına varması ve becerileri yüksek bireylerin bilim alanlarına yönlendirilmesi yükümlülüğü okullara aittir. Tarih boyunca bu yükümlülüklerini yerine getiren okullara sahip olan toplumlar medeniyeti yakalayacaktır. Bu bakış açısıyla ülkeler, bilimsel düşünebilen nesiller yetiştirme ve genç nüfusu bilim alanlarında kariyer yapmaya teşvik etme eğilimindedir. Dolayısıyla bireylerin bilim alanlarında kariyer yapması için küçük yaşlardan itibaren teşvik edilmeleri gerekmektedir. Çünkü bilim insanı olabilmek, daha küçük yaşlardan itibaren bilime duyulan ilgi, merak ve sevgi ile başlamaktadır. $\mathrm{Bu}$ da öğrencilerin daha küçük yaşlardan itibaren tohumlarını atacakları bilim kimliği ile daha köklü bir hale gelebilir.

Alan yazın incelendiğinde bireylerin bilim alanlarında kariyer yapmayı tercih etmelerini etkileyen iki temel faktör dikkati çekmektedir. Bunlardan biri, bireyin bilim ve bilim insanına 
yönelik algısı ve bireyin kendine ilişkin bilgisidir. Flavell (1979)'in ortaya koyduğu üstbilişsel bakış açısıyla baktığımızda bireyin bilim insanının yaptığı işe yönelik bilgisi, görev bilgisidir. $\mathrm{Bu}$ bilgi, birey bilim alanlarında kariyer yapmayı düşündüğünde neler yapması gerektiğine yöneliktir. Görev bilgisi yetersiz ve abartılı olması durumunda bireyin bilim alanlarında kariyer yapma eğilimi azalacaktır. Kendine yönelik bilgi ise, bilim alanının gerektirdiği bilgi ve yeteneklerin hangilerine sahip olduğuna yöneliktir. Birey yetenekleri ve bilgisi ile görevin beklentilerinin ne kadarını karşıladığına karar vererek kendine yönelik bir inanç oluşturur. Bu inanç çerçevesinde performansı ve motivasyonu şekillenir. Benzer çerçeveden vurgu yapan Cleaves (2005) araştırmasında, on altı yaşından sonra bilim seçimine karşı iki güçlü etken tespit etmiştir. Birincisi; bilim meslekleri ve bilimle ilgili bilgi eksikliğinden kaynaklanmaktadır. İkincisi ise; öğrencilerin bilimle ilgili kabiliyetlerini zihinlerinde canlandırırken yapabileceklerinden daha düşük bir öz yeterliğe sahip olmalarıdır.

Bireyin bilim alanlarında kariyer yapması ile ilgili kendine yönelik oluşturduğu inanç, alan yazında bilim kimliği olarak tanımlanmaktadır. Bilim kimliği, öğrencilerin bilimde neyi yapabileceklerine inandıkları ve ne yapmak istedikleri ile ilgili algılarıdır (Brickhouse, 2001). $\mathrm{Bu}$ algı, insanların çabası sonucu şekillenen sosyal bir yapı olarak görülmektedir (Brickhouse ve Potter, 1999; Brickhouse, Lowery ve Schultz, 2000). Bu bakımdan bilim kimliği; bireyin evdeki, okuldaki ve günlük yaşamındaki sosyal etkileşimlerinden yani onların yaşadığı tecrübelerden etkilenerek şekillenmektedir (Jones, Taylor ve Forrester, 2011). Bilim kimliği gelişimine tecrübenin ve yaşadığı toplumun etkisinin yanı sıra Carlone ve Johnson (2007) ile Archer, vd. (2010), bireylerin bilim kimliklerinin üzerine cinsiyet, etnik köken ve sosyoekonomik düzeyin de etkisinin olduğunu ileri sürmüşlerdir. Özellikle etnik kökeni farklı olan toplumların kültürleri de farklıdır. Bu kültür farklılığı toplumsal cinsiyet algılarında farklılık yaratmakta ve bireylerin bilim kimlikleri üzerine cinsiyetin etkisini ortaya çıkarmaktadır. Aslında cinsiyetin bilim kimliği üzerine etkisinin temelinde toplumun kültürü ve toplumsal cinsiyet algısı yatmaktadır. Karaçam ve Digilli-Baran (2017) ortaokul öğrencilerinin bilim insanının cinsiyetine yönelik algılarını tespit ettikleri çalışmaları sonucunda araştırmaya katılan birçok bireyin yaşadığı toplumda hakim olan toplumsal cinsiyet algısı temelinde bilim insanını ya kız ya da erkek olarak tanımladıklarını bulmuşlardır. Araştırmada örneğin, "Bilim insanları çok çalışırlar. Kadınlar çocuk bakmaktan, yemek yapmaktan zaman ayıramazlar. Ama erkeklerin böyle bir görevi yoktur. Bu nedenle bilim insanları erkektir." şeklinde toplumsal cinsiyete ilişkin bir algı vurgulanmıştır. Bu algının hakim olduğu bir toplumda yetişen bir kadın bilim alanlarında kariyer yapmayı ne kadar düşünebilir? Bu sonuç göstermektedir ki, bireylerin bilim dünyasında yer almalarını bireylerin yaşadıkları toplumun toplumsal cinsiyet algısı belirlemekte; onları bilimden uzaklaştırmakta ya da yakınlaştırmaktadır.

Bireylerin bilim kimliklerini etkileyen en önemli faktörlerden birisi; fen derslerinin içeriği ve dolayısıyla bireylerin fen derslerine yönelik algılarıdır. Osborne ve Collins (2000)'e göre öğrencilere fen derslerinde bilimle ilgili aşırı yükleme yapılmakta ve genellikle bilim, günlük hayat ile ilişkilendirilmemektedir. Hatta bununla ilgili olarak gençlerin diğer derslere kıyasla daha fazla başarısız olduğu dersin, fen dersi olduğu belirtilmiştir (Jenkins ve Nelson, 2005; Lyons, 2006; Osborne ve Collins, 2001; Archer vd., 2010). Bu nedenle fen dersi öğrenciler açısından zor bir ders olarak görülmektedir (Carlone, 2004). Benzer şekilde düşünen İngiltere'deki ve Slovenya'daki birçok ortaokul öğrencisi fen dersini zor, sıkıcı, cazibesiz ve yaratıcı olmayan bir şey olarak nitelendirmiştir (Braund ve Reiss, 2006; White ve Harrison, 
2012). Öğrenciler, fen dersi kapsamındaki bilimi ise analitik düşünme, problem çözme ve teknik yetenek bakımından dönüştürülebilir beceriler olarak görmemişlerdir. Öğrencilere göre bunu en iyi yapabilenler; çalışkan ya da akıllı öğrenciler olup bu öğrenciler "öğretmen her şeyi basitleştirerek anlatmasın, biz de düşünüp, beynimizi kullanalım” fikrindedirler. Bu ise beyni yormaktadır. Dolayısıyla zeki insanlar iyi bilim insanı olabilirler ancak zeki de olsa insanlar bilimle uğraşırken çabalar ve beynini yorarlar (Archer vd., 2010). Sonuçta fen dersinin içeriği nedeniyle bilim insanı olmak ile zeki olmak arasında bir bağ kurmuşlardır. Bu bakış açısına sahip bireylerin birçoğu birçok şeyi başarmış olsalar bile bilimde ilerlemek için kendilerini yeterince zeki görmemekte ve bilim kimlikleri olumsuz etkilenmektedir (Cleaves, 2005).

Bireylerin bilim kimliklerini etkileyen bir diğer faktör bireylerin bilim insanına yönelik algısıdır. Bireyler bilim insanını günlük hayatta yolda yanlarından geçen bir şahıs olarak algılayamamaktadırlar. Son yarım asırdır ülkemiz dahil çeşitli ülkelerde yapılan çalışmalarda (She, 1998; Çermik, 2013) bireylerin bilim insanının genel olarak gözlüklü, laboratuvar önlüklü, saçı sakalı birbirine karışmış, kimyasal maddeler ve araç-gereçlerle laboratuvarda tek başına hiç durmadan çalışan erkek olarak algıladıkları ileri sürülmüştür. Mead ve Metraux (1957) tarafından basmakalıp bilim insanı imgesi olarak tanımlanan bu algının bireylerin bilim alanlarında kariyer yapma eğilimlerini olumsuz etkilediği ileri sürülmektedir (She, 1998). Hiç durmadan izbe bir laboratuvarda çalışan bir bilim insanı imgesi çerçevesinde bireyler bilim insanının dışa dönük olmaktan ziyade içedönük, insan odaklı olmaktan ziyade görev odaklı, sosyal olmaktan ziyade duygusuz ve kelimelerle iletişim kurmaktan çok diyagramlar üzerinde konuşmayı sevenler olarak algılamaktadırlar (Woolnough, Guo, Leite, Almeida, Ryu, Wang ve Young, 1997). Yani bilim insanı asosyal, duyguları olmayan bir robot gibi düşünülmektedir. Bu da bilim insanı olmak isteyenler için aslında sosyolojik bir risktir.

Basmakalıp bilim insanı imgesi çerçevesinde bireyler bilim insanını kimyasal malzemelerle deney yapan bir erkek olarak algilamaktadırlar. Bu nedenle bireyler deneyler esnasında kazalar olabileceğini düşünmektedirler. Archer vd. (2010), çocukların okulda yaptıkları bilimin "güvenli bilim" olduğunu, fakat 'gerçek bilimin' ya da 'bilim insanlarının yaptığı bilimin', "tehlikeli bilim" olduğunu söylemektedirler. Bu konuda hem erkekler hem de kızlar bilimi "patlamalarla" "gürültülerle" ve "sıvıların dökülmesiyle oluşacak tehlikelerle" ilişkilendirmişlerdir. Bu nedenle de bilim insanlarının tehlikeli deneylerle uğraşmalarından ya da yaptıkları bilimde çeşitli tehlikelerle karşılaşabileceklerini düşündüklerinden onların risk altında çalıştıklarını ve bilim insanı olmak istemediklerini belirtmişlerdir. Yani bilimle ilgili "bilim yapmak" ve "bilim insanı olmak" arasında ciddi bir kopukluk yaşamaktadırlar (Osborne ve Dillon, 2007). Buradan yola çıkılarak öğrencilerin algılarının "gerçek bilim" ve "okuldaki bilim" diye ikiye ayrıldığ görülmektedir (Venville, Rennie, Hanbury ve Longnecker, 2013). Okuldaki bilim algısı feminizm teorisiyle ilişkilendirilerek güvenli bulunmuş, gerçek bilim algısı ise maskülinizm ile ilişkilendirilerek tehlikeli, riskli vb. bulunmuştur. Venville vd. (2013) toplumun bilime karşı tutumlarını; okuldaki bilime karşı tutumlar ve bir meslek olarak bilime karşı tutumlar diye ayrı ayrı incelemişlerdir. Çünkü birçok öğrenci özellikle de erkekler, bunzen beki gibi ateşle oynamayı umut etmekte ve daha önce yaptıkları bilimi (tehlikeler barındırmadığ 1 için) gerçek bilim olarak görmemektedirler. Öğrenciler, okuldaki bilimi, gerçek bilime kıyasla daha cazip görmektedirler (Archer vd., 2010). Örneğin, gelecekte bilim yapmaya devam etmek istemeyen bir kız öğrenci "Kimyasallar tarafından havaya uçacak bir başım olsun istemem" ifadesiyle aslında bilim insanı olmakla ilgili kendinde çağrışım yapan riski 
belirtmiştir. Bilim insanlarının karşı karşıya kalacağı "patlamalar" ve "tehlikeler" üzerine kızlardan çok erkeklerin yorum yapması da bu düşüncenin sadece kızlarda değil erkeklerde de olduğunu göstermektedir. Onlara göre bilim insanları, öğrencilerin okulda yaptıkları bilimden daha tehlikeli işler yapmaktadır. Çünkü öğrencilere göre; okul öğrencilere güvenli bir ortam sağlarken, bilim insanlarının çalışma alanları yeterince güvenli olmamaktadır. Hatta bazı öğrenciler, asitleri vs. kullanarak okulda büyük patlamalı deneyler yapmalarına izin verilmediğinden, bu durumdan yakınmıştır.

Sadece çok zeki, entelektüel ya da aydın diyebileceğimiz kimselerin bilim insanı olabileceğini düşünen öğrenciler de vardır. Bilim insanı deyince, onların akıllarına ırk, yaş, cinsiyet ve sınıf bakımından beyaz ırktan, orta yaşlı, erkek, saçı başı dağılmış ve orta sınıftan olan bir bilim insanı gelir (Karaçam, Aydın ve Digilli, 2014). Çocukların yaşı ilerledikçe bilim kimlikleri oluşurken, bilim insanına ilişkin zihinlerindeki basmakalıp bilim insanı imajı, kendilerini sınıftan dışlanmış biri gibi hissettirmektedir. Dolayısıyla çok az öğrenci kendince bu riski göze alabilmektedir. Bu sebeple de kız öğrenciler, zihinlerindeki basmakalıp bilim insanı imaj1 sebebiyle kendilerini bir bilim insanı olarak hayal edememektedirler (Archer vd., 2010; Baker ve Leary, 1995; Jenkins ve Nelson, 2005).

\section{Araştırmanın Alan yazındaki Yeri}

2004 yılından bugüne Milli Eğitim Bakanlığı tarafından yürürlüğe konulan fen dersi öğretim programlarının amaçlarında, bireylerin bilim alanında kariyer yapmaya teşvik edilmesi özellikle vurgulanmasına rağmen ülkemizde bireylerin bilim alanlarına olan tercihleri giderek azalmıştır. Alan yazında bireylerin bilim alanlarını tercih etmelerinin temel nedeninin onların bilim kimlikleri olduğu ileri sürülmektedir. Bilim kimliğini etkileyen en önemli faktörlerin, bireylerin bilim ve bilim insanı algılarının olduğu ileri sürülmüştür. Bu tespitler, önemli tespitlerdir. Fakat araştırmalar, bireyin neden bilim alanında kariyer yapmayı tercih etmediğine yönelik resmi tam verememektedir. Dolayısıyla bu çalışmada bireylerin bilim insanı olmanın riskli olduğunu düşünmeleri ve bu riskleri üstlenmek istemediklerinden bilim insanı olmak istemedikleri varsayılmıştır. Bu bakış açısıyla bireylerin bilim insanının sahip olduğu risklere yönelik algıları tespit edilmeye çalışılmıştır. Bu risk algısının bireylerin bilim ve bilim insanı algısı temelinde oluştuğu düşünülebilir. Fakat çalışmada ortaya konulacak risk algıları daha spesifiktir ve bireylerin bilim insanlığı yolundaki düşünsel engelleri sergilemektedir. Bu açıdan çalışmanın sonuçlarının bireyleri bilim alanında kariyer yapmaya cesaretlendirmek için yapılacak uygulamalara yön vermesi beklenmektedir.

\section{Araştırma Sorusu}

Ortaokul öğrencilerinin bilim insanının sahip olduğu risklere yönelik algıları nelerdir?

\section{Araştırmanın Amacı}

$\mathrm{Bu}$ çalışmanın amacı, ortaokul öğrencilerine göre, öğrencilerin bir bilim insanının sahip olduğu risklere ilişkin algılarını tespit etmektir. 


\section{Yöntem}

\section{Araştırma Deseni}

Ortaokul öğrencilerinin bilim insanının sahip olduğu risklere ilişkin algılarını tespit etmeye yönelik yapılan bu çalışmada, ortaokul öğrencilerinin bilim insanının sahip olduğu risk kavramına yükledikleri ortak anlamlar tespit edilmeye çalışılmıştır. Bu nedenle bu çalışmada nitel araştırma tekniklerinden fenomenoloji kullanılmıştır (Cresswell, 2013). Bu çalışmada öğrencilerin -her ne kadar deneyimleri az olsa da- gerek görsel medyadan gerek kitaplardan gerekse günlük yaşamdaki başka kaynaklardan deneyimledikleri "Bilim insanı olmanın riskleri" konusundaki deneyimlerinin özü ortaya konulmaya çalışılmıştır. Benzer şekilde Cresswell, fenomenolojide veri analiz edilirken, önemli ifadeler, anlamlı birimler yani içerikteki öze vurgu yapmıştır. Bu çalışmada da bilim insanı olmanın riskini betimleyen öğrencilerden toplanan verilerde özellikle bu riske yönelik özünde hangi riski ifade etmeye çalıştıkları tespit edilmeye çalışılmıştır. Dolayısıyla bu çalışmada ortaokul öğrencilerinin risk fenomenine yükledikleri ortak anlamlar tespit edilecektir.

\section{Katılımcilar}

Araştırmaya Düzce ilindeki beş ortaokulun beş, altı ve yedinci sınıflarında öğrenim gören 592 (erkek=294, kız=298) öğrenci katılmıştır. Okul ve öğrencilerin belirlenmesinde herhangi bir seçime gidilmemiştir. Okulların belirlenmesi sürecinde dikkate alınan en önemli kriter, fen bilimleri öğretmenin çalışmaya yönelik gönüllüğü ve okulun ulaşılabilirliğidir. Araştırmacıların ulaşması kolay olan öğretmenlerin sınıflarında uygulamalar yapması dolayısıyla kolay ulaşılabilir örnekleme ile örneklem seçimi yapılmıştır (Yıldırım ve Şimşek, 2011). Okullar belirlendikten sonra tüm okullarda bulunan tüm beş, altı ve yedinci sınıf şubelerine uygulama yapılmıştır. Fakat çalışmaya sekizinci sınıfların merkezi sınava hazırlanmaları ve bu tür etkinlikleri önemsememeleri nedeniyle, sekizinci sınıflar çalışma grubuna dahil edilmemiştir. Çalışmaya katılan öğrencilerin sınıf ve cinsiyetlerine göre dağılımları Tablo 1'de sunulmuştur.

Tablo 1. Öğrencilerin cinsiyet ve öğrenim gördükleri sınıflara göre frekans ve yüzde dağılımları

\begin{tabular}{ccccccc}
\hline \multirow{2}{*}{ Öğrenim Düzeyi } & \multicolumn{2}{c}{ Erkek } & \multicolumn{2}{c}{ Kız } & \multicolumn{2}{c}{ Toplam } \\
& f & \% & f & \% & f & \% \\
\hline $\mathbf{5}$ & 102 & 17.23 & 111 & 18.75 & 213 & 35.98 \\
$\mathbf{6}$ & 97 & 16.38 & 96 & 16.22 & 193 & 32.60 \\
$\mathbf{7}$ & 95 & 16.05 & 91 & 15.37 & 186 & 31.42 \\
Toplam & 294 & 49.66 & 298 & 50.34 & 592 & 100 \\
\hline
\end{tabular}

\section{Uygulama ve Veri Toplama Aracı}

Araştırmada uygulama 2014-2015 öğretim y1lı bahar döneminde yapılmıştır. Uygulamada öğrencilerin bilim insanının sahip olduğu risklere yönelik algılarını belirlemek için açık uçlu bir sorudan oluşan yapılandırılmış görüş formu araştırmacılar tarafından hazırlanmıştır. Bu görüş formunun daha önce otuz kişilik bir ortaokul öğrenci grubu ile pilot çalışması yapılmış olup, pilot çalışma sonucu öğrencilerin cevapları gözden geçirilerek görüş formuna son şekli verilmiştir. Bu soru "Bilim insanı olmanın riskleri sizce nelerdir? Neden böyle düşündüğünüzü açıklayınız." şeklindedir. Bu şekilde öğrencilerden bilim insanının sahip olduğu risklerin neler olduğu ve neden böyle düşündüklerini açıklamaları istenmiştir. Uygulamada katılımcıların 
cevaplarını yazmaları için süre sınırı verilmemiş olup, cevaplarını tamamlayanların kâğıtları toplanmıştır.

\section{Veri Analizi}

Araştırmada yapılandırılmış görüş formunda elde edilen veriler içerik analizi ile analiz edilmiştir. Bu kapsamda ilk olarak veriler bir kodlayıcı tarafından gözden geçirilmiş ve boş bırakılan veya araştırma sorusu ile ilgili cevaplar vermeyen öğrencilerin verileri veri setinden ayıklanmıştır. Bu aşamada iki kodlayıcı bir araya gelmiş ve veri setinden çıkartılması öngörülen verilerin makullüğu tartışılmıştır. $\mathrm{Bu}$ tartışma sonucunda araştırma sorusu ile ilgili cevaplar vermeyen öğrencilerin tüm verilerinin veri setinden çıkarılmasına karar verilmiştir. Verilerin analizinde ikinci aşamasında asıl kodlamaya geçilmiştir. Kodlama alanında uzman iki kodlayıcı tarafından yapılmıştır. Kodlama sürecinde her elli katılımcıda bir en başa dönülmüştür. $\mathrm{Bu}$ verilen kodların tutarlığını sağlamıştır. Kodlama sonucunda veri setindeki verilere 1115 kod verilmiştir. Daha sonra Miles ve Huberman (1994)'ın güvenirlik formülü (Güvenirlik=Görüş birliği/ (Görüş ayrıllğı + Görüş ayrılığı)) kullanılarak iki kodlayıcının verdiği kodların \% 93 oranında tutarlı ve güvenilir olduğu bulunmuştur. Son aşamada ise verilen kodlar arasındaki örüntüye bakmak için iki kodlayıcı bir araya gelmiştir. İki kodlayıcı verilen kodlar arasındaki örüntü üzerine tartışarak, benzer özellikte olan ifadeleri bir araya getirip kodlardan kategoriler, kategorilerden de temalar oluşturmuştur.

\section{Bulgular}

Araştırmada öğrencilerin verdikleri yanıtlardan 1115 risk ifadesi tespit edilmiş ve 3 tema ortaya çıkmıştır. Temalar; "Bilim İnsanını Etkileyen Riskler"( $\mathrm{f}=1002, \% 89,9)$, "Çevreyi ve Toplumu Etkileyen Riskler" (f=83, \%7,4) ve "Araç, Gereç ve Deneklere Yönelik Riskler" (f=30, \%2,7) olarak adlandırılmıştır (Şekil-1). Çevreyi ve toplumu etkileyen riskler ile araç gereç ve deneklere yönelik riskler teması altında toplanan ifadeler bu araştırmanın yaklaşık \%10'unu oluşturmaktadır. Bu nedenle bu temalar altında çeşitlendirilebilecek çok sayıda kategori ve kod oluşturulamamıştır. Bunun sebebi, bu iki temaya atfedilecek fazla çeşitte düşüncenin bulunmamasıdır. $\mathrm{Bu}$ nedenle aşağıda bu temalardan en az atıf alan temadan en çok atıf alan temaya doğru öncelikle "Araç Gereç ve Deneklere Yönelik Riskler" ve "Çevreyi ve Toplumu Etkileyen Riskler"e yönelik bulgular verilmiştir. Daha sonra ise araştırmanın neredeyse tamamını kaplayan "Bilim İnsanını Etkileyen Riskler" teması altında toplanan kategoriler ve bu kategorilere ait kodlara yönelik bulgular verilmiştir.

\section{1- $\quad$ Araç Gereç ve Deneklere Yönelik Riskler}

Bilim insanı olmanın riskleri konusunda, verdikleri yanıtlarla öğrencilerden çok azı $(f=30$, $\% 2,7)$ araç gereç ve deneklere yönelik risklerden bahsetmiştir. Bu öğrencilerden Fahriye: "Laboratuvardaki aletler bozulabilir. Örneğin dinamometre ile çok ağır bir şeyler ölçsek dinamometre bozulur" diyerek araç gereçlere yönelik riskler olduğunu belirtirken, Yasemin:

"Deney için kullanılan deneklerde hastalıklar görülebilir ve ölebilirler... Bir hayvanın canına kastedebilirler" diyerek deneklere yönelik de riskler olduğunu belirtmiştir. 


\section{2- $\quad$ Çevreyi ve Toplumu Etkileyen Riskler}

Öğrencilerin bazılarının ( $(=83, \% 7,4)$ verdikleri yanıtlar "Çevreyi ve Toplumu Etkileyen Riskler" temasını oluşturmuştur. Verilen cevaplar doğrultusunda kümelenmiş kodlar bulunmadığından bu tema alt kategorilere ayrılmamıştır. Bu riskler; deney yüzünden etrafı su basabilir, yangın çıkabilir, patlama olursa etrafa bir madde döküldüğü zaman o döküldüğü yeri yakabilir gibi risklerdir. Öğrencilerden;

Sibel: "Bilim insanının icadı kötü ellere geçerse hiç de iyi şeyler olmaz. Örneğin; silahı kim icat etmişse bence cennete giremez. Sonuçta o adam yüzünden milyonlarca şehit verdik"

Berkan: "Mesela uzman bir doktorun yanlış teşhis sonucu yanlış ilaçlar vermesi, hastasının ölümüne sebep olabilir"

Tuğba: "Bulunan iyi icatlar bazen insanlara bağımlılık yapabilir (internet, TV vs.)"

Kerem: "Bilim insanları atomlarla ve nükleer bombalarla uğraşır. Mesela Çernobil'de bir nükleer facia oldu. Bilim insanlarının dikkatsizliği yüzünden her yer mahvoldu ve tüm insanların ölümüne sebep oldu”

Zeliha: "Yanlış madde üretirlerse pek çok insanın hayatını tehlikeye atabilirler, etrafa zehirli gazlar saçılabilir ve insanlar için zararlı olur"

Sibel, Berkan, Tuğba, Kerem ve Zeliha'nın bilim insanı olmanın risklerine yönelik ifadelerine bakıldığında, bilim insanının çevreyi ve toplumu etkileyebilecek risk algılarının olduğu görülmektedir. Şekil-1'de de görüldüğü üzere, bu risk algılarından en çok kod ve kategorinin oluşturulduğu tema "Bilim İnsanını Etkileyen Riskler" temasıdır. Hatta bu temaları oluşturan 20 kod ve 5 kategorinin tamamı "Bilim İnsanını Etkileyen Riskler" başlığı altında gelişmiştir. Dolayısıyla bu kısım ayrıntılı olarak aşağıda sunulmuştur.

\section{3- Bilim İnsanını Etkileyen Riskler}

Öğrencilerin neredeyse tamamı ( $\mathrm{f}=1002, \% 89,9)$ "Bilim İnsanını Etkileyen Riskler" teması altında toplanmıştır (Şekil-1). Şekil-1'de bu temayı oluşturulan kategoriler; Fiziksel ( $\mathrm{f}=659$, \%59,1), Sosyolojik ( $\mathrm{f}=153, \% 13,7)$, Psikolojik ( $\mathrm{f}=101, \% 9,1)$, Emeğe Yönelik ( $\mathrm{f}=80, \%$ \%,2) ve Ekonomik ( $\mathrm{f}=9, \% 0,8)$ Riskler olarak beş kategoriye ayrılmıştır. Bu kategoriler ve bunlara ait kodlar en çok atıf alandan en az atıf alana doğru aşağıda sırasıyla sunulmuştur. 


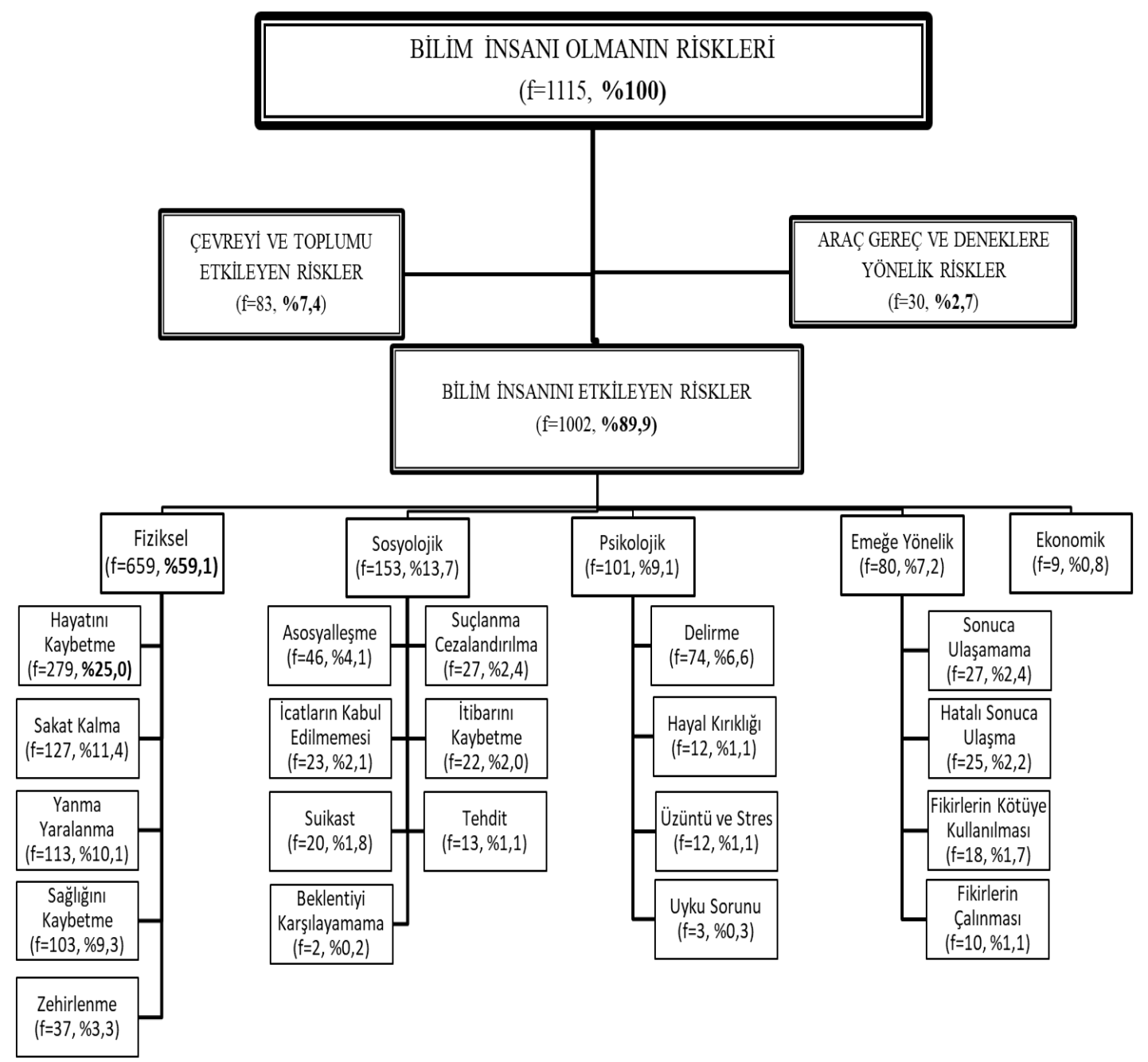

\section{Şekil 1. Bilim İnsanı Olmanın Riskleri}

\section{Fiziksel riskler}

Bilim insanına yönelik fiziksel riskleri oluşturan kodlar şunlardır: Hayatını Kaybetme ( $\mathrm{f}=279$, \%25,0), Sakat Kalma ( $\mathrm{f}=127, \% 11,4)$, Yanma Yaralanma ( $\mathrm{f}=113, \% 10,1)$, Sağlığını Kaybetme $(\mathrm{f}=103, \% 9,3)$ ve Zehirlenme $(\mathrm{f}=37, \% 3,3)$ (Şekil-1). Öğrencilerin bilim insanını etkileyen fiziksel risklerden en çok hayatını kaybetme olarak nitelendirdikleri risklere yoğunlaştıkları görülmüştür.

(a) Hayatın Kaybetme. Bilim insanını etkileyen risklerden "hayatını kaybetme" koduna yönelik çok ciddi sayıda bulgu ortaya çıkmıştır. Çünkü her dört ifadeden biri bu koda atfetmektedir. Bilim insanının hayatını kaybetmesinin çeşitli sebeplerini ise öğrenciler; hatalı bulgular sonucu, patlama sonucu ve kimyasallarla temas ve zehirlenme sonucu hayatını kaybetme olarak belirtmişlerdir. 
Hatalı bulgular sonucu hayatını kaybetme riskini, Elif: "Deneyinde bi yanlışlık yapsa ve deneyinin başarısız olması sonucunda kötü şeyler ortaya çıkabilir ve deney yaparken yanlış yapması sonucu genç yaşta ölebilir" şeklinde ifade ederken, Saliha: "Hata yaparlarsa zarar görebilirler, çünkü ölümcül risk vardır" demiştir. Muzaffer ise; "Deneylerinde zehirli hayvanlart incelerken hata olursa bilim insanının ölümüne sebep olur" diyerek hatalı bulguların bilim insanının ölümüne sebebiyet verebileceğini söylemiştir.

Patlama sonucu hayatını kaybetme riskini"Mesela deney yaparken yanıcı bir şey kullanabilir, yanlışlıkla o patlar. Bilim insanının canına mal olur" ve "Bence çok riskli bir meslek. Yani atıyorum, bir deney yapıyorsun, laboratuvarda ortalık patlar filan ölürsün” diye belirten Ayşe ve Mehmet de herhangi bir patlamada bilim insanının hayatını kaybedebileceği riskine dikkat çekmiştir.

Bilim insanının kimyasallarla temas ve zehirlenme sonucu hayatını kaybetme riskinin olabileceğini de Zehra: "Bilim insanları fazla deney yaptıkları için ve kimyasallarla fazla iç içe oldukları için mesela zehirli gazlardan etkilenip, deney yaparken ölebilirler" şseklinde belirtmiştir.

(b) Sakat Kalma. Sakat kalma riskini, Barış: "Kimyasal maddelerle uğraşırken onlar gözlerimizin kör olmasına sebep olabilir" diye açıklamaya çalışırken Nurullah: "Yaptığın bir deney yüzünden kolunda bacağında, yüzünde veya herhangi bir yerinde kalıcı kötü hasar olabilir" şeklinde açıklamıştır. Ayrıca Ahmet de "Deney yaparken patlama sonucu elimizin ayağımızın kopması ... "diyerek bu riski vurgulamıştır.

(c) Yanma Yaralanma. Yanma yaralanma riskinin sebeplerini belirten öğrenciler daha çok (1) patlama sonucu yanma yaralanma, (2) kesici aletler sebebiyle yaralanma, (3) kimyasallar sonucu yanma yaralanma, (4) elektriğe çarpılma ve (5) deneklerin yaralaması gibi çeşitli nedenlerden kaynaklanabileceğini belirtmiş̧lerdir. Bu maddelere örnek olarak;

Esra: “Deney tüpleri patlayıp camları bilim insanının vücuduna saplanabilir”(1)

Hacer: "Bir deney yaparken yanlışlıkla elini kesebilir ve kesici maddeler bir yerlerine zarar verebilir"'(2)

Hakan: “Asit gibi yakıcı kimyasal maddeler üzerine gelirse yanabilir...bir ilaç yaparken ellerine eldiven giymezse cildi tahriş olabilir"(3)

Ali: "Elektrikli bir deney yapıyorsunuz kabloları yanlış bağladınız, çarpılabilirsiniz. Edison yanlış yapsa elektrik çarpardı"(4)

Emin: "Zehirli hayvanı incelerken sizi sokup yaralayabilir" (5) demiştir.

(d) Sağlığını Kaybetme. Bilim insanının sağlığını kaybetmesine verilen örneklerden en çok öne çıkanlar şöyledir: Bilgisayar başında çok oturmaktan gözlerinin bozulması, bel ve boyun ağrılarının oluşması, çok çalıştı̆̆ için beyninin, kalbinin yorulması ve kalp krizi geçirme riski gibi risklerdir. Bilim insanının sağlığını kaybetmesine yönelik olarak, kimyasallarla uğraştığı için virüs veya mikrop kapması, kanser gibi hastalıklara yakalanabilme ihtimalinin yüksek olması ve radyasyona maruz kalması gibi sebeplerden kaynaklandığını söyleyenler de vardır. Bunlardan Betül: "Radyasyonlu alanlarda (Röntgen, Emar, Tomografi gibi) radyasyon yayan araçlar sağlığını bozabilir” derken, Hasibe: “...zehirli otları ve hayvanları inceliyorlar. Bunlar zararlı ve hastalıkl ise virüs kapabilirler" diye belirtmiş̧tir. Hasan: "Bilim insanları 
gece gündüz çalışlyorlar, dinlenmezlerse hasta olabilirler" diyerek bilim insanlarının normalden daha fazla çalıştıkları için sağlıklarını kaybedebileceklerine dikkat çekmiştir.

(e) Zehirlenme. Bilim insanını etkileyen fiziksel risklerden bahseden Erva: "Deney yaparken mesela civa gibi zehirli bir maddeden zehirlenebilir" diyerek, bilim insanını fiziksel olarak etkileyen zehirlenme riskini vurgulamıştır.

\section{Sosyolojik riskler}

Bilim insanına yönelik sosyolojik risk algısı kategorisini yedi kod oluşturmuştur. Bunlar; Asosyalleşme $(\mathrm{f}=46, \% 4,1)$, Suçlanma-Cezalandırılma $(\mathrm{f}=27, \% 2,4)$, İcatların Kabul Edilmemesi ( $\mathrm{f}=23, \% 2,1)$, İtibarını Kaybetme $(\mathrm{f}=22, \% 2,0)$, Suikast $(\mathrm{f}=20, \% 1,8)$, Tehdit $(\mathrm{f}=13$, $\% 1,1)$ ve Beklentiyi Karşılayamama $(\mathrm{f}=2, \% 0,2)$ şeklindedir. Öğrencilerin bilim insanını etkileyen sosyolojik risklerden en çok asosyalleşme kodunda nitelendirdikleri risklere yoğunlaştıkları görülmüştür.

(a) Asosyalleşme. Bu kategorideki öğrenciler, bilim insanının hayatının çoğunu işiyle geçirdiği için özel hayatı ve sosyal hayatı olmayacağı yönünde fikir yürütmüşlerdir. Bunlardan Sema: "Ailelerinden ve arkadaşlarından uzaklaşır, yalnız kalırlar. Araştırma ve deneyler yapayım diye ailesi ile görüşüp, hasret gideremezler. Bilimle ilgilenmekten aileleriyle vakit geçiremezler" diye belirtmiştir. "Hayatları laboratuvarda geçer. Dünyadan ilişkisini koparırlar, kimseyle görüşmezler" diyen Nihal ve bilim insanlarıla arkadaş olmanın sıkıcıllı̆̆ından bahseden Büşra: "Bulduğu buluşun olumsuz etkileri olduğunda ve bunu insanlar kullandı̆̆ında diğer insanlar tarafindan dışlanabilir" diyerek bu durumun bilim insanını asosyalleşmeye doğru sürükleyebileceğine değinmiştir.

(b) Suçlanma-Cezalandırılma. Bilim insanlarının, insanlar için yararlı icatlar bulmadıklarında çevredekilerin tepki gösterip bilim insanını suçlaması veya cezalandırmasını risk olarak gören öğrencilerden Mustafa: "Hayvanlar üstünde deney yaparlarken hayvan severlerin tepkisini alabilirler..." demiştir. Gülay: "Görüşleri doğru bulunmayıp idam ettirilebilirler. Bir şey bulur da keşfederse (Galileo gibi) ona inanmayanlar onu öldürebilir yalan söylüyorsun diye” diyerek Mine'nin "Bilim insanının söylediği yanlı̧̧ bir şey ispatlanırsa ya da yanlış buluş yaparsa bilim insanı ceza alabilir hatta hapse bile girebilir" ve Dilek'in "Kendi buluşunu düzgünce anlatamazsa hırsızlıkla ve yalancılıkla suçlanabilir" sözlerini desteklemiştir.

(c) İcatların Kabul Edilmemesi. Öğrencilerden Zeynep: “İnsanlar bulunan buluşları kabul etmeyebilir" diye düşünürken Merve de: "Bilim insanlarının geçmişte de çok riskler aldı̆̆ görülebiliyor. Örneğin; Galileo Dünya'nın döndüğünü söylemiş. Ama o zamanki insanlar bunu kabul etmemiş" diye belirtmiştir. Fatih: "Yaptıklart icatlar diğer bilim insanları tarafından beğenilmeyebilir" demiştir. Böylece bilim insanının icatlarının kabul edilmemesini de bir risk olarak görmüşlerdir.

(d) Itibarını Kaybetme. Bilim insanı kendini ifade edemezse yaptığ buluş ne kadar büyük olursa olsun başkalarını ikna edip araştırmasını açıklayamazsa, itibarının kaybolmasına sebep olabileceği düşünülmüştür. Öğrencilerden, Ramazan'ın “Yapacağı icatlar ileride kötü olaylara sebep olabilir ve bu yüzden tarih boyunca kötü bir üne sahip olabilir. Yani evvel günde vezir iken yeni doğan günde rezil olabilirler” sözü, Engin'in: “Buldukları şey işe yaramazsa küçümsenirler, dalga geçilir ve rezil olabilirler, bu yüzden de gerilerler” sözleri ve İsmail'in 
“İ̧e yaramaz bir icat yaptığımızda bir sonraki işe yarayan icatlarımızı kimse takmaz” sözleri bu durumu desteklemektedir. Şerife'nin "Bilim insanı evlenemeyerek türünün devamın sağlayamayabilir" sözüyle de bilim insanının neslini devam ettiremediğinde de itibarını kaybedebileceğine değinmiştir.

(e) Suikast. Bilim insanını etkileyen bir diğer sosyolojik risk unsuru suikast kategorisinde toplanmıştır. Öğrencilerden, Abdullah: "Bir teori ortaya attığında onu doğru bulmayanlar tarafindan öldürülebilirler” diyerek bu konuya değinmiştir.

(f) Tehdit. Bilim insanının çeşitli sebeplerden tehdit edilebileceğini düşünen Rukiye: "Buluşlarını kötü yönde kullanması için tehdit edilebilirler” Gönül: "Ülkesini kurtarmak için buluş yaptıklarında diğer ülkeler tarafindan tehdit edilebilirler" demiştir. Recep: "Bilim insanını kaçırıp bulduğu önemli icadı yapmaya zorlarlar" diyerek bilim insanlarının bu hususta tehdit altında olduğunu dile getirmiştir.

(g) Beklentiyi Karşılayamama. Sosyolojik risklerden biri olarak değerlendirilen bu kod için, Osman: "Ünlü bir bilim insanı olursak, halkın beklentisi çok olur ve halkın beklentisini karşılayamayabiliriz" ifadesini kullanmıştır.

\section{Psikolojik riskler}

Bilim insanını etkileyen psikolojik riskler; Delirme ( $\mathrm{f}=74, \% 6,6)$, Hayal Kırıklığı $(\mathrm{f}=12, \% 1,1)$, Üzüntü ve Stres $(\mathrm{f}=12, \% 1,1)$ ve Uyku Sorunu $(\mathrm{f}=3, \% 0,3)$ olmak üzere dört koddan meydana gelmiştir. Öğrencilerin, bilim insanını etkileyen psikolojik risk olarak en çok delirmeye vurgu yaptıkları görülmüştür.

(a) Delirme. Bilim insanlarının çok düşünmekten delirebileceğini bir şeyi bulmaya çalışırken, çözemediği bir sorun karşısında çok deneyip yapamayınca akli dengesini yitirip kafayı yiyebileceğini bir risk unsuru olarak gören öğrencilerden Fatma: "Çok çalışmaktan kafayı yiyorlar ve deliriyorlar" Hamide: "Bilim insanları bizim için çalışıyorlar... bize yararları da olsa çok yoruluyorlar. Bir işe beyinlerini yoruyorlar ve gitgide delirmeye başllyorlar" Benzer şekilde Ayşe: "Bir şey düşünüyorsan, bulamayınca delirirsin. Eğer ki bir şeyi çok çok denedin ama olmadl. O zaman psikolojin bozulur." Fadim ise: "Bilim insaninin bence en büyük riski delirme ihtimalidir. Bir icat yapayım der, on kere dener, yapamazsa aklını kaybedebilir" demiştir.

(b) Hayal Kırıklı̆̆. Bilim insanlarının buluşları ya da başarıları sonucunda bekledikleri gibi iyi sonuç alamadıkları zaman başlarına gelebilecek bir risk faktörü olarak "hayal kırıklı̆̆ı" kodunun oluşmasında Serhat: "Bir icat yaptıklarında ve o icadı aslında başka birinin çıktığında o zaman hayal kırıklı̆ı̆na ŭgrar" ve Kamil: "Halktan iyi tepki alamayınca içine kapanabilirler" demiştir. Benzer şekilde Fırat: "Ĕ̆ger sağllk alanı için ilaç yapıyorsan ve o insan ölürse vicdan azabı çekersin. Sonuçta hayal kırlklı̆̆ olur" diyerek bunun bir psikolojik risk olduğunu dile getirmiştir.

(c) Üzüntü ve Stres. Bilim insanlarının eğer bir işi başaramazsa, istedikleri sonuca ulaşamazsa üzülüp stres yapabileceğini düşünen öğrencilerden Ömer: "Çok çalışıp strese girer. Aşırı derecede stres yaparlar" İbrahim: "İcadı ĕger kimsenin ilgisini çekmezse üzülür" ve Münir: "Deney yaparken stresli olurlar. Istedikleri sonuca ulaşamayınca çok üzülürler. Başarısızlı̆̆a uğradıkça psikolojik olarak sorun yaşayabilirler” diye belirtmişlerdir. 
(d) Uyku Sorunu. Bilim insanlarının sürekli olarak zihinlerinin meşgul olduğunu ifade eden Hüsniye: "Uyku sorunu yaşayabilirler” diyerek bu soruna değinmiştir.

\section{Emĕge yönelik riskler}

Bilim insanının emeğine yönelik riskler; Sonuca Ulaşamama ( $\mathrm{f}=27, \% 2,4)$, Hatalı Sonuca Ulaşma ( $\mathrm{f}=25, \% 2,2)$, Fikirlerin Kötüye Kullanılması $(\mathrm{f}=18, \% 1,7)$ ve Fikirlerin Çalınması $(\mathrm{f}=10, \% 0,9)$ şeklinde kodlanmıştır.

(a) Sonuca Ulaşamama. Bilim insanının emeği sonucunda istediği sonuca ulaşamaması ve böylece başarısız olmasının onun için risk olduğunu belirten öğrencilerden Seher: "Bilim insanı olmak çok zor... İsmini duyuramazsan, kariyerin başlamadan biter ve yaptığın şey çöp olur (-)" Duygu: "Bilim insanı olmak zor iştir. Herkes senden bir şeyler bekler. Ve olumsuz bir üretimde haksız olabilirsin. Böylece emeklerin boşa gider” Armağan: “...Patentini almadan başkasına kaptırabilir sonra da bilimle uğraşmaz" Aylin: "Birçok deneme yapılsa da başaramama olasılığı vardır" Burcu: "İcadın her şeyini bitirip tamamlamaya hazırlanırken yanlı̧̧ yaparsa icat çöpe gider ve baştan yapmak zorunda kalabilir, emeklerine yazık olur" diyerek sonuca ulaşamama riskine değinmiştir.

(b) Hatalı Sonuca Ulaşma. Bilim insanının en ufak bir hatası sonucu istenmedik sonuçlara ulaşabileceğini düşünen öğrencilerden Tahir: "ilaç üretiminde yanlı̧̧ malzeme kullanırsak yeni bir hastalık ortaya çıkabilir" Alper: "Yanlış yaptı̆̆ bir deney sonucunda virüslerin oluşmasına neden olabilir" demiştir. Aynı düşünceyle İlker: "Bir canlının genleri ile oynayıp onu insanlı̆̆a karşı kötü bir yaratık yapmasıdır" derken, Aydın: "Yanlış bir deney yapınca bunun sonucunda zor durumda kalabilirler" diyerek hatalı sonuca ulaşmanın bilim insanı için bir risk olduğunu ifade etmişlerdir.

(c) Fikirlerin Kötüye Kullanılması. Bilim insanının insanlığa faydalı buluşlar yapma niyetiyle yola çıkmasına rağmen ortaya çıkardığı ürünün ya da fikirlerinin kötüye kullanılması da bir risktir. Böyle düşünen öğrencilerden Dilara: "Bir icat yapıldı̆̆ında (örneğin silah) iyiye mi kullanılacak kötüye mi bilemeyiz ve risk alırız" ve Neriman: Insanlar atomu insanlığa faydalı olacağını düşündükleri için bulmuşlardır. Ama insanlar onu kötü yönde kullandıkları için atom bombası ile binlerce insanın ölümüne yol açmışlardır" demiştir. Damla: "Buluşları kötü emeller için kullanılabilir” diyerek bunun da bilim insanı için risk olduğunu belirtmiştir.

(d) Fikirlerin Çalınması. Bilim insanının fikirlerinin çalınabileceğini söyleyen Gökçen: "Bir fikir buluyorlar ve o buldukları şeyi başkası yapabilir, yaptığı deneyler ve icatlar çalınabilir" demiştir. Nurcan: "Yaptığın deneylere başkaları ben yaptım diyerek sahip çıkabilir" diye belirtmiş ve bunun doğru olmadığını söylemiştir. Böylece bilim insanının fikirlerinin kıymetli olduğu için bu fikirlerin çalınabilme riskinin olduğunu ifade etmişlerdir.

\section{Ekonomik riskler}

Bilim insanını etkileyen riskler arasında yer alan ekonomik risklere $(\mathrm{f}=9, \% 0,8)$ de bazı öğrenciler dikkat çekmiştir. Örneğin; Burhan: "Buldukları buluşlar insanlar için ihtiyaç haline gelirse para içinde yaşarlar. Lakin yararlı olmazsa daha çok çalışma yapmak için de para bulamazlar" Kağan: "Deney malzemeleri alırken, maddi sikıntıya girebilirler" ve Ersan: "Ülkeye faydalı şeyler kazandırmak için çok pahalı şeyler kullansalar da bir şey yapamasalar çok paraları gider" demiştir. Ayrıca "Bilim insanları deney (bilim) yapamazsa para 
kazanamazlar. Ĕger yeni icatlar bulamazlarsa para kazanamazlar ve maddi sikıntıya düşebilirler" diyen Alican da bilim insanına yönelik ekonomik risklerin varlığına değinmiştir.

\section{Sonuç, Tartışma ve Öneriler}

Tek ham maddeleri insanların beyin gücü olan ülkelerin geleceği, bilim ve teknolojide ne kadar geliştiklerine bağliyken (Lamanauskas ve Augiene, 2011) birçok ülkedeki gençlerin bilim alanında kariyer yapma eğilimlerinin düşük olması dikkati çekmiştir. Yapılan araştırmalar incelendiğinde -ülkemizde de olduğu gibi- öğrencilerin ortaokula geçiş sırasında bilime karş1 olan ilgilerinin azaldığı (Hutchinson, Stagg ve Bentley, 2009; Osborne, Simon ve Collins, 2003; Archer vd., 2010; White ve Harrison, 2012; Cerinsek vd., 2013) ve ilerleyen eğitim hayat1 boyunca sürekli azalan sayıda öğrencinin bilim derslerini çalışmayı seçtiği (Lyons ve Quinn, 2010) ya da yaşları ilerledikçe ileride bilimle ilgili meslek seçmek istemedikleri (Jenkins ve Nelson, 2005) görülmüştür. Benzer şekilde ülkemizde de fen dersi öğretim programlarının amaçlarında, bireylerin bilim alanında kariyer yapmaya teşvik edilmesi gerektiği özellikle vurgulanmasına rağmen bireylerin bilim alanlarına olan tercihleri giderek azalmıştır. Bu ilginin azalmasında birçok neden olsa da bunun en önemli nedenleri arasında öğrencilerin bilim ve bilim insanına yönelik sahip oldukları risk algılarının olduğu öngörülmüştür. Çünkü alan yazında öğrencilerin sahip olduğu basmakalıp bilim insanı imgesi nedeniyle bilim ve bilim insanına yönelik olumsuz tutum geliştirdikleri belirtilmesine rağmen bunun risk algısından kaynaklanabileceğine yönelik bir araştırmaya rastlanmamıştır. Bu bakımdan bu araştırmada ortaokul öğrencilerinin bilim insanının sahip olduğu risklere yönelik algıları tespit edilmeye çalışılmıştır.

Araştırma sonucunda, kariyer seçiminde bilim insanı olmanın riskleri ile ilgili olarak bin yüz on beş risk ifadesi tespit edilmiş ve bu risklerden üç tema ortaya çıkmıştır. Bu temalar: bilim insanını etkileyen riskler; çevreyi ve toplumu etkileyen riskler; araç, gereç ve deneklere yönelik riskler olarak adlandırılmıştır. Bu temalar arasında çevreyi ve toplumu etkileyen riskler ile araç gereç ve deneklere yönelik riskler teması altında toplanan ifadeler bu araştırmanın çok az bir kısmını oluşturmuştur. Özellikle çevreyi ve toplumu etkileyen riskler temasına öğrencilerin çok az vurgu yapması, onların ya bilim insanının yaptığı faaliyetlerin çevre ve toplum üzerindeki etkisine yönelik farkındalıklarının çok düşük olduğu ya da bilim insanlarının yaptığ 1 faaliyetlerin genellikle çevre ve toplum için yararlı olduğunu düşündüklerini akla getirmektedir. Başka bir deyişle böyle bir sonuç elde edilmesinin nedeni; ya öğrencilerin bilimin doğasına yönelik anlayışlarının zayıf olmasıyla ya da onların bilim insanına yönelik imgeleri gerçek bir insan yerine toplumsal bir kahraman yönünde olmasıyla açıklanabilir. Fakat elimizde bu ikilemi çözmemizi sağlayacak veri bulunmamaktadır. Bu bakımdan farklı bir çalışmada bilim insanının sahip olduğu çevreyi ve toplumu etkileyen risklerin neler olduğu ve bu düşüncelerin temelinde yatan faktörlerin incelendiği bir çalışma yapılmalıdır.

Araştırmanın bulgular kısmının neredeyse tamamını kaplayan tema "bilim insanını etkileyen riskler" teması olmuştur. Bu tema altında toplanan kategoriler ve bu kategorilere ait kodlar incelendiğinde, öğrencilerin bilim insanının fiziksel, ekonomik, sosyolojik, emeğe yönelik ve psikolojik risklere sahip olduklarını belirttikleri bulunmuştur. Öğrencilerin en fazla fiziksel riskler temasına vurgu yaptıkları ve bu temada ise en fazla patlama sonucu yaralanma veya ölme riskine vurgu yaptıkları görülmüştür. Böyle bir sonuç elde edilmesi doğaldır. Çünkü 
risk kavramı denildiğinde, bir bireyi olumsuz etkileyecek bir olay çağrışmakta ve bu bir bilim insanı olduğundan direk bir patlama sahnesi insanın gözünde canlanmaktadır. Benzer şekilde ekonomik riskler temasında da patlama sonucu mal varlığını kaybetme kategorisi en fazla vurgulanan kategori olmuştur. Öğrencilerin en fazla vurgu yaptıkları diğer bir tema olan sosyolojik riskler temasında ise toplumdan uzaklaşma veya evlenememe riski görülmüştür. $\mathrm{Bu}$ algının temelinde ise, bilim insanı hiç durmadan çalışır, algısı yatmakta olup bu algı "Bilim insanı asosyaldir." kavramsallaştırmasına yol açtığı düşünülebilir. Bilim insanının çok çalışmasını temel alarak öğrencilerin bir başka riski de öne sürdükleri dikkati çekmiştir. Bu risk, psikolojik riskler teması altındaki çok çalışmaktan delirme riskidir. Öğrencilere göre bilim insanı bilim yaparken çok çaba sarf etmektedir. Çünkü onlara göre bilim yapmak kolay değildir. $\mathrm{Bu}$ kadar emek sarf ettikten sonra sonuca ulaşamama büyük bir hüsrandır. Bu bakış açısıyla öğrenciler bilim insanının emeğine yönelik riskler teması altında en fazla çalışma sonucuna ulaşamama riskine vurgu yaptığı sonucuna ulaşı1mıştır.

Araştırmanın en can alıcı sonucu olarak, bilim insanını etkileyen fiziksel risklere ilişkin bulgulardan; hayatını kaybetme, sakat kalma, yanma yaralanma, sağlığını kaybetme ve zehirlenme ile ilgili olarak Archer vd. (2010) çalışmasındaki çocukların okuldaki bilimin "güvenli bilim" olduğunu fakat gerçek bilimin "bilim insanları tarafından yapılan tehlikeli bilim" olduğu bulgusunu desteklemektedir. O halde Venville vd. (2013) nin de belirttiği gibi öğrencilerin algılarının "okuldaki bilim" ve "gerçek bilim" diye ikiye ayrılmasının ardındaki nedenin öğrencilerin bilim insanına yönelik risk algılarından kaynaklandığı düşünülebilir. Araştırmanın sonuçları arasında yer alan bilim insanını etkileyen psikolojik risk bulguları ile Archer vd. (2010)'nin çalışmasında bilim insanının zeki bile olsa bilimle uğraşırken çabalayıp beynini yorduğu sonucu ile örtüşmektedir. Araştırmada bilim insanını etkileyen sosyolojik risk bulguları ile de bilim insanının asosyal ve duyguları olmayan bir robot gibi düşünüldüğü Woolnough, vd. (1997)'nin araştırmasını destekler niteliktedir.

Araştırma sonuçlarına göre, bireylerin birçok risk algısının basmakalıp olduğu ve basmakalıp bilim insanı imgesi temeline dayandığını göstermektedir. Çünkü öğrenciler, bilim insanını her gün dışarıda karşılaştıkları sıradan insanlardan farklı bir kimlikle algılamaktadırlar. $\mathrm{Bu}$ algılarında onlara göre, bilim insanlarının diğer insanlardan farklı olarak üstlendikleri riskler ön plana çıkmaktadır. Buna patlama sonucu hayatını kaybetme, ekonomik variyetini kaybetme riskleri örnek verilebilir. Bu riski ifade eden öğrencinin bilim insanına yönelik gözünün önünde canlanan resim laboratuvarda kimyasal malzeme ve araç gereçlerle deneyler yapan bir kişidir. Bir başka örnek olarak çok çalışmaktan delirme riski veya evlenememe riski verilebilir. Bu riskleri ifade eden öğrencilerin bilim insanının sahip olduğu riskler denildiğinde gözlerinin önünde canlanan resim saatlerce hiç kimse ile görüşmeden tek başına çalışan bir kişi olabilir. Bu imgeler bizi basmakalıp bilim insanı imgesine götürmektedir. Bireylerin bilim insanı imgelerini tespit etmeye yönelik yapılan çalışmalarda (Ağgül-Yalçın, 2012; Karaçam, 2015; Karaçam ve Digilli-Baran, 2017; Öcal, 2007; Toğrol, 2000) basmakalıp bilim insanı imgesini ifade ederken benzer risk ifadelerini de belirttikleri dikkati çekmektedir. Fakat bunun net resmini çizmek için bir başka çalışmada ilk başta öğrencilere bilim insanına yönelik imgesi çizdirilmeli ve bu resim üzerinden çizdiği bilim insanının sahip olduğu risklere yönelik görüşme yapılmalıdır. Bu şekilde basmakalıp bilim insanı temelli risk algıları betimlenmiş olacaktır. 
$\mathrm{Bu}$ araştırma sonucunda öğrencilerin bilim insanlarının birçok riske sahip olduklarını algıladıkları görülmesinin yanında, sorgulanması gereken en önemli noktalardan biri de bu risk algısının kaynağı, diğeri ise bu risk algısının öğrencilerin bilim alanlarında kariyer yapma eğilimleri üzerine etkisidir. Bireylerin bilim insanının sahip olduğu risk algılarının kaynağına yönelik herhangi bir çalışma olmamasına rağmen bireylerin basmakalıp bilim insanı imgelerinin kaynağı olarak ders kitapları (Karaçam, Aydın ve Digilli, 2014), basılı ve görsel medya (Türkmen, 2008) gibi faktörler ileri sürülmektedir. Her ne kadar risk algılarının kaynağ 1 bu çalışmanın odağının dışında olsa bile, gerek öğrencilerin riskleri ifade ederken kullandıkları cümleler gerekse de basmakalıp bilim insanı imgesinin kaynağına yönelik alan yazın bizi öğrencilerin risk algılarının kaynaklarından birinin de basılı ve görsel medya olduğunu düşündürmektedir. Örneğin suikast riski koduna vurgu yapan öğrenciler, bilim insanının önemli bilgiler bulması nedeniyle bir başka devlet tarafindan öldürülebileceğini düşünmektedirler. $\mathrm{Bu}$ düşünce bizi filmlerde koruma altına alınan bilim insanı sahnesine veya gazetelerdeki “Aselsan'da önemli projeler yürüten mühendislerin şüpheli ölümü” başl1klı haberleri çağrıştırmaktadır. Bir başka örnek fikirlerinin çalınması koduna vurgu yapan bireylerdir. Bu konu gerek çizgi filmlerde gerekse filmlerde sık kullanılan sahnedir. Dolayısıyla bu çıkarımları, yani risklerin kaynağını ve basılı ve görsel medyada bilim insanının sahip olduğu riskleri empoze ediliş şeklini betimleyen çalışmaların yapılması gerekmektedir.

Sorgulanması gerektiğini düşündüğümüz ikinci soru bu risklerin bireylerin bilim alanlarında kariyer yapma eğilimleri üzerine etkisidir. Benzer şekilde bu soru çalışmanın odağı dışındadır. Fakat öğrencilerin ifade ettikleri risklere ilk bakışta, hayatını kaybetme, sakat kalma, suikaste uğrama, toplum tarafından dışlanma veya cezalandırılma gibi riskler çok ağır risklerdir. $\mathrm{Bu}$ riskleri göze alarak bilim alanında kariyer yapmaya karar vermek düşündürücüdür. Bu risk algılarının öğrencilerin öz yeterliklerini düşüreceği ve bilim alanında kariyer yapma eğilimlerinin azalacağı düşünülebilir (Cleaves, 2005). O halde bu sorunsala yönelik çalışmalar yapılması gerekmektedir. Bu yönde yapılacak çalışmalarda risk algısı ile bilim alanında kariyer yapma eğilimi arasındaki ilişki yanında, hangi risk algısının bilim alanında kariyer yapmayı daha olumsuz etkilediğini sergilemek olmalıdır.

Sonuç olarak bu çalışmada öğrencilerin bilim insanının çevre ve topluma, araç, gereç ve deneklere ve kendine yönelik birçok riske sahip olduklarını algıladıkları bulunmuştur. Öğrencilerin en fazla bilim insanının kendine yönelik risklere sahip olduğunu düşündükleri sonucuna ulaşılmıştır. Ulaşılan bu sonuç, alan yazında bu yönde bir çalışmanın olmaması nedeniyle önemli bir sonuçtur. Fakat bu çalışmada öğrencilerin risklere yönelik kullandıkları ifadeler çözümlenirken, öğrencinin bilim insanı olarak zihninde canlandırdığı resimdeki kişinin bilimsel bir faaliyet yaparken sahip olduğu riskleri ifade edip etmediği dikkate alınmamıştır. Çünkü öğrencilerin ifadeleri irdelendiğinde bazı ifadelerde öğrencilerin bir bilim insanından ziyade bir mucit (teknoloğu) canlandırdığg ve buna göre cevap verdiği dikkati çekmektedir. $\mathrm{Bu}$ bakımdan bundan sonraki çalışmalarda bu ayrımın yapılması ve bilimsel faaliyetleri sonucunda bilgi ortaya koymayı amaçlayan bilim insanının sahip olduğu risklerin sergilenmesi gerekmektedir. Fakat toplumumuzda bilim ve teknoloji birbiri ile çok karıştırıldığından bunun gerçekleştirilmesi de güçtür. Bu sonuçlar öğretmenlerin öğrencilerini bilim alanlarına kariyer yapmalarını teşvik etmek için aşmaları gereken bazı engelleri göstermektedir. Fakat bu risk algılarının tümünün öğrencilerin kariyer seçimleri üzerine etkisinin olduğu konusu halen açık ve net değildir. Bu nedenle öğrencilerin risk algılarının kaynağının, basmakalıp bilim insanı imgesi 
ile ilişkisi ve bireylerin kariyer yapma eğilimleri üzerine etkisi araştırmacılar tarafından irdelenmelidir. Bu irdelemenin sonrasında ise, belirlenen risk algılarını revize etmeye yönelik yaklaşımlar geliştirilmeli ve bu uygulamaların etkililiği test edilmelidir. 


\section{Kaynakça}

Ağgül Yalçın, F. (2012). Öğretmen adaylarının bilim insanı imajlarının bazı değişkenler açısından incelenmesi, Illkögretim Online, 11(3), 611-628.

Anagün, Ş.S. ve Yaşar, Ş. (2009). Developing scientific process skills at science and technology course in fifth grade students, Illkögretim Online, 8(3), 843-865.

Archer, L., DeWitt, J., Osborne, J., Dillon, J., Willis, B., \& Wong, B. (2010). "Doing" science versus "being" a scientist: Examining 10/11-year-old schoolchildren's constructions of science through the lens of identity. Science Education, 94(4), 617-639.

Baker, D. \& Leary, R. (1995). Letting girls speakout about science, Journal of Research in Science Teaching, 32(1), 3-27.

Braund, M. \& Reiss, M. (2006). Towards a more authentic science curriculum: The contribution of outof-school learning. International Journal of Science Education, 28(12), 1373-1388.

Brickhouse, N.W. (2001). Embodying science: A feminist perspective on learning. Journal of Research in ScienceTeaching, 38(3), 282-295.

Brickhouse, N.W.,Lowery, P., \& Schultz, K. (2000). What kind of a girl does science? The construction of school science identities. Journal of Research in Science Teaching, 37(5), 441-458.

Brickhouse, N.W. \& Potter, J.T. (1999). Young women's scientific identity formation in an urban context. Journal of Research in Science Teaching, 38, 965-980.

Carlone, H.B. (2004). The cultural production of science in reform-based physics: Girls' access, participation, and resistance. Journal of Research In Science Teaching, 41(4), 392-414.

Carlone, H.B., \& Johnson, A. (2007). Understanding the science experiences of successful women of color: Science identity as an analytic lens. Journal of Research in Science Teaching, 44(8),11871218.

Cerinsek, G., Hribar, T., Glodez, N. \& Dolinsek, S. (2013). Which are my Future Career Priorities and What Influenced my Choice of Studying Science, Technology, Engineering or Mathematics? Some Insights on Educational Choice-Case of Slovenia, International Journal of Science Education, 35(17), 2999-3025, DOI:10.1080/09500693.2012.681813

Cleaves, A. (2005). The Formation of Science Choices in Secondary School, International Journal of Science Education, 27(4), 471-486, DOI: 10.1080/0950069042000323746

Creswell, J.W. (2013) Research Design: Qualitative, Quantitative, and Mixed Methods Approaches. 4th Edition, SAGE Publications, Inc., London.

Çermik, H. (2013). Öğretmen adaylarının zihinlerinde canlanan resimdeki bilim insanı, Pamukkale Üniversitesi Eğitim Fakültesi Dergisi, 33 (1), 139-153.

Flavell, J. H. (1979). Metacognition and cognitive monitoring: A new area of cognitive-developmental inquiry. American Psychologist. 34(10), 906-911.

Hutchinson, J., Stagg, P. \& Bentley, K. (2009). STEM Careers Awareness Timelines: Attitudes and ambitions towards science, technology, engineering and maths (STEM at KeyStage 3). Derby: International Centre for Guidance Studies (iCeGS).

Jenkins, E. \& Nelson, N.W. (2005). Important but not for me: Students' attitudes toward secondary school science in England. Research in Science and Technological Education, 23(1), 41-57.

Jones, G., Taylor, A. \& Forrester, J. H. (2011). Developing a Scientist: A retrospective look, International Journal of Science Education, 33(12), 1653-1673.

Karaçam, S., Aydın, F. ve Digilli, A. (2014). Fen Ders Kitaplarında Sunulan Bilim İnsanlarının Basmakalıp Bilim İnsanı İmajı Açısından Değerlendirilmesi. Ondokuz Mayıs Üniversitesi Eğitim Fakültesi Dergisi, 33 (2), 606-627. 
Karaçam, S. (2015). Secondary school students' perceptions about scientist: Metaphorical analysis. Mustafa Kemal Üniversitesi Sosyal Bilimler Enstitüsü Dergisi, 12(29), 190-222.

Karaçam, S. ve Digilli-Baran, A. (2017). The origins of perceptions regarding gender of scientist among secondary school students. Hacettepe Üniversitesi Eğitim Fakültesi Dergisi, 32(3), 727-744. doi: 10.16986/HUJE.2017027508.

Lamanauskas, V. \& Augiene, D. (2011). Scientific research activity evaluation: Lithuanian upper secondary school students' position, Journal of Baltic Science Education, 10(3), 195-208.

Lyons, T. (2006). Different countries, same science classes: Students' experience of school science classes in their own words. International Journal of Science Education, 28(6), 591-613.

Lyons, T. \& Quinn, F. (2010). Choosing science. Understanding the declines in senior highschool science enrolments. Armidale, NSW: University of New England.

Mead, M. \& Metraux, R. (1957). Images of the scientists among high-school students. Science, 126, 384390.

Miles, M. B., \& Huberman, A. M. (1994). An expanded sourcebook qualitative data analysis. Thousand Oaks, California: Sage Publications.

Osborne, J. \& Collins, S. (2000). Pupils' views of the school science curriculum, report funded by the Wellcome Trust (London: King'sCollege).

Osborne, J. \& Collins, S. (2001). Pupils' views of the role and value of the science curriculum: A focusgroup study. International Journal of Science Education, 23, 441-467.

Osborne, J. \& Dillon, J. (2007). Research on learning in informal contexts: advancing the field? International Journal of Science Education, 29(12), 1441-1445.

Osborne, J. F., Simon, S. \& Collins, S. (2003). Attitudes towards science: A review of the literatüre and its implications. International Journal of Science Education, 25(9), 1049-1079.

Öcal, E. (2007). İlköğretim 6, 7 ve 8. slnıf ögrencilerinin bilim insanı hakkındaki imaj ve görüşleri. Yayınlanmamış Y. Lisans Tezi. Gazi Üniversitesi Eğitim Bilimleri Enstitüsü:Ankara.

She, H. (1998). "Gender and grade level differences in Taiwan students' stereotypes of science and scientists", Research in Science and Technological Education, 16(2), 125-135, DOI:10.1080/0263514980160203.

Sturman, L., Ruddock, G., Burge, B., Styles, B., Lin, Y. \& Vappula, H. (2008). England's achievement in TIMSS 2007: National report for England. Slough: NFER.

Toğrol A. (2000). Ögrencilerin bilim insani ile ilgili imgeleri, Egitim ve Bilim, 25(118), $49-57$.

Türkmen, H. (2008). Turkish primary students' perceptions about scientist and what factors affecting the image of the scientists. Eurasia Journal of Mathematics, Science and Technology Education, $4(1), 55-61$.

Venville, G., Rennie, L., Hanbury, C. \& Longnecker, N. (2013). Scientists reflect on why they chose to study science. Research in Science Education, 43 (6), 2207

Yıldırım, A. ve Şimşek, H. (2011). Sosyal bilimlerde nitel araştırma yöntemleri. (8. Baskı). Ankara: Seçkin Yayıncılık.

White, E.L. \& Harrison, T. G. (2012). UK School Students' Attıtudes Towards Science and Potential Science-Based Careers, Acta Didactica Napocensia. 5(4), 1-10.

Woolnough, B. E., Guo, Y., Leite, M. S., Almeida, M. J., Ryu, T., Wang, Z. \& Young, D. (1997). Factors affecting student choice of career in science and engineering: parallel studies in Australia, Canada, China, England, Japan and Portugal, Research in Science and Technological Education, 15(1), 105-121, doi:10.1080/0263514970150108. 


\section{Extended Abstract}

\section{Introduction}

As in our country, when the scientific researches are examined, it is observed that students' interest towards science decreased during the transition to secondary school (Hutchinson, Stagg \& Bentley, 2009; Osborne, Simon \& Collins, 2003; Archer et al., 2010; White \& Harrison, 2012; Cerinsek et al. 2013) and decreasing numbers of students chose to study science courses during their education life progressively (Lyons \& Quinn, 2010) or they did not want to choose a profession related to science as they got older (Jenkins \& Nelson, 2005). Although there are many reasons for this decrease in interest, it is predicted that students' perceptions of risk to science and scientists are among the most important reasons. Because, although it is stated in the literature that students' develop negative attitudes towards science and scientists because of students' stereotyped image of scientists, no research has been found that this may be caused by risk perception. In this respect, this study is aimed to determine the perceptions of secondary school students' about the risks of science.

\section{Methodology}

In this study, it is tried to specify the common meanings of secondary school students' risk concept of the scientist. Therefore, phenomenology, one of the qualitative research techniques, was used (Cresswell, 2013) in this study. In the research, common meanings of risk phenomenon -which secondary school students' have- were determined. 592 (male $=294$, female $=298$ ) students in fifth, sixth and seventh grades of different five secondary schools are participated in the study, in Duzce. The participants were asked to explain what the risks of the scientist are and to explain why they think so. The data obtained were analyzed through content analysis. The coding was done by two coders who are specialists in the field. As a result of coding, 1115 codes were given to the data in the data set. The consistency of the given codes was examined and it was found that $93 \%$ of the codes given by the two encoders were consistent. In the last stage, two encoders came together to look at the pattern between the given codes. The two encoders discussed the pattern between the given codes. Then, they have identified the themes, together.

\section{Conclusion, Discussion and Suggestions}

As a result of the research, one thousand one hundred and fifteen risk expressions have been determined regarding the risks of being a scientist and three themes have emerged from these risks. These themes are named as: risks affecting scientist; risks affecting the environment and society; risks intended for tools, materials and subjects. Among these themes, the statements gathered under the theme of risks affecting the environment and society and risks to the equipment and subjects are constituted a very small part of this research. Particularly emphasis on the theme of risks that affect the environment and society suggests that participants either have a low awareness of the impact of the activities of the scientist on the environment and society or that brings to mind the participants think the activities of scientists are generally beneficial to the environment and society.

Almost all of the findings of the research is composed of "risks affecting scientist". It is observed that the participants emphasized the most physical risks category under this theme and 
the highest risk of injury or death due to explosion under this category. Such a result is natural. Because when the concept of risk is mentioned, it evokes an event that will affect an individual negatively and since it is a scientist, a direct explosion scene is visualized of the human being. Similarly, in the economic risks category, the most emphasized thing was the loss of assets after explosion. The highest risk of ostracization or not getting married was observed in sociological risks. On the basis of this perception, the scientist works nonstop, this idea lies at the bottom of this perception. It can be thought that this perception leads to the conceptualization of "Scientist is asocial". Based on the hard work of the scientist, it was noted that the participants posed another risk. This risk is the risk of maddening because of working hard under the theme of psychological risks. According to the participants, the scientists make a lot of effort while doing science. Because, science is not easy for them. It is a great disappointment that they have not been able to reach the conclusion after so much effort. From this point of view, it was concluded that students emphasized the risk of not make good at consequence under the theme of risks to the labor oriented of the scientist.

As the most crucial result of the research, the findings support Archer et al. (2010)'s research related to the physical risks affecting the scientist; in relation to loss of life, disability, burning injury, loss of health and poisoning. They stated that children at school are saying "safe science" but that are saying real science is "dangerous science made by scientists". As Venville et al. (2013) are saying, it can be thought that the reason behind the division of students' perceptions into "science at school" and "real science" are stem from students' perceptions of risk about scientists'. The psychological risk findings affecting the scientist and Archer et al. (2010)'s study is similar to the conclusion that the scientist strives and exhausts his brain while dealing with science, even if he is intelligent. And sociological risk findings that affect the scientist is similar to Woolnough, et al. (1997)'s research. They stated that the scientist is thought to be a robot who is asocial and emotionless.

At the first glance of the risks expressed by the students -such as; loss of life, disability, assassination, exclusion or punishment by the society- are very serious risks. As a result of this research, it is seen that students perceive that scientists have many risks. In addition, one of the most important points to be questioned is the source of this risk perception and the other is the effect of this risk perception's on students' tendency to pursue a career in science. Because, it is difficult to decide to take the plunge, make a career in science. It can be thought that these risk perceptions will decrease students' self-efficacy and their tendency to make a career in science (Cleaves, 2005). Therefore, studies need to be carried out for this problem. Thus, the source of students' perceptions of risk, the relationship between stereotyped image of scientists and the effects of these risks on individuals' career tendencies can be examined. After this review, approaches should be developed to revise the risk perceptions identified and the effectiveness of these practices should be tested. 